\title{
The Enhancement of Sustainable Competitiveness of the CEE Regions at the Time of the COVID-19 Pandemic Instability
}

\author{
Małgorzata Dziembała
}

check for updates

Citation: Dziembała, M. The Enhancement of Sustainable Competitiveness of the CEE Regions at the Time of the COVID-19 Pandemic Instability. Sustainability 2021, 13, 12958. https://doi.org/ $10.3390 /$ su132312958

Academic Editor: Bruce Morley

Received: 26 September 2021 Accepted: 17 November 2021 Published: 23 November 2021

Publisher's Note: MDPI stays neutral with regard to jurisdictional claims in published maps and institutional affiliations.

Copyright: (C) 2021 by the author. Licensee MDPI, Basel, Switzerland. This article is an open access article distributed under the terms and conditions of the Creative Commons Attribution (CC BY) license (https:/ / creativecommons.org/licenses/by/ $4.0 /)$.
Department of International Economic Relations, University of Economics in Katowice, 40-287 Katowice, Poland; malgorzata.dziembala@ue.katowice.pl

\begin{abstract}
The promotion of competitiveness of regions is a key issue nowadays. However, because of the COVID-19 pandemic and the consequences of territorial dimension it caused, the approach towards the concept of regional competitiveness needs to be reformulated in which the sustainability perspective is underlined. Thus, the composition of factors that determine regional competitiveness should be redefined in a way that not only economic but to a greater degree social and concurrently environmental factors need to be considered. The objective of the paper is to discuss the concept of sustainable regional competitiveness and to identify factors that are of utmost importance for this regional competitiveness. The position of particular CEE regions in light of the selected indicators that could determine sustainable competitiveness has been examined. The analysis has allowed us to identify some factors that are crucial for sustainable regional competitiveness in the regions of CEE countries to enable achieving long-term growth in the sustainable manner. This study contributes to the research through proposing some factors that could reflect particular dimensions of sustainable competitiveness in CEE regions, by providing a measure of sustainable competitiveness and through identifying the position of CEE regions in terms of sustainable competitiveness. The support of these key factors may be taken into consideration while planning the interventions within the regional policy.
\end{abstract}

Keywords: sustainable competitiveness; regional competitiveness; COVID-19; regions; resilience; EU; Central and Eastern European countries

\section{Introduction}

The COVID-19 pandemic brought about some instability in the world economy. There are different repercussions in many spheres, not only economic but social and environmental as well. They are diversified, also on the regional level. Especially the regions of Central and Eastern Europe (CEE) countries, which joined the EU in 2004 and which are characterised by a low level of economic development, could be severely affected and face serious challenges. Thus, they should make some efforts to enhance their resilience in the face of instability and changing external environment due to the pandemic. In the long term, they should increase their competitiveness.

The enhancement of competitiveness, including territorial units, through supporting some factors that marked such competitiveness is a key issue nowadays [1-4]. Regions should constantly improve their competitive position, also in relation to other regions located in different countries. However, the COVID-19 pandemic drew special attention to its social and environmental repercussions. Thus, the approach to competitiveness has been reformulated. The position of regions in the international environment should be shaped taking into consideration not only economic but also social and environmental perspectives. Competitiveness, also on the regional level, should be promoted in a sustainable manner and this approach is currently discussed [1] (p. 632).

The objective of this paper is to discuss the concept of sustainable regional competitiveness at the pandemic time and to identify factors that are crucial for this kind of regional 
competitiveness. The position of particular CEE regions in light of the selected indicators has been examined.

Taking into consideration the aforementioned discussion, the following research questions were formulated:

Research Question 1 (RQ1): What factors are essential for creating regional sustainable competitiveness?

Research Question 2 (RQ2): What is the position of CEE regions in terms of sustainable competitiveness?

Nowadays, the concept of regional competitiveness, including sustainable competitiveness, is being discussed $[1,2,5]$. However, the novelty of this research is that it identifies factors that could reflect the dimensions of sustainable competitiveness in CEE regions and set their position. The measure of sustainable competitiveness has also been proposed. This comprehensive approach has been neglected in research so far.

The following thesis has been formulated: The enhancement of sustainable regional competitiveness requires the promotion of specific factors for each dimension of competitiveness in CEE regions.

The following methods were applied: the analysis of literature, induction and deduction, factor analysis.

The paper consists of three parts. The first part concentrates on the discussion concerning the concept of regional sustainable competitiveness and its role in promoting resilient regional economies at the time of COVID-19. The second part examines factors that characterise different dimensions of sustainable competitiveness in the CEE regions that are identified. The ranking of CEE regions in terms of sustainable competitiveness has also been presented. The next two parts of the paper include discussion and conclusions.

\section{Promotion of Regional Sustainable Competitiveness in the COVID-19 Pandemic-Literature Review}

\subsection{A Regional Dimension of the Impact of the COVID-19 Pandemic}

The COVID-19 pandemic impact is of unprecedented scale as it has affected more than 50 million people all over the world. Lockdowns and containment measures were imposed on more than half of the world's population [6] (pp. 2-3). The pandemic has had diversified effects on the development of countries and their regions. The impact on demand and supply and the negative effects on the world economy [7], not only in particular countries, is underlined. Particular fields such as international trade, foreign direct investment flows, global production, and employment affected by COVID-19 [8,9] have been discussed. The social impact of the pandemic reflected in poverty, mostly experienced by women, has been analysed [10]. The impact of the pandemic on ecology and the energy sector has also been presented [11].

Bailey et al. 2020 stresses that the impact of the pandemic geographically is unevenly distributed. It has been regional rather than national, and the variations of the impact and its intensity are high within countries [12,13] (pp. 32-37). Not only economic but social, employment, and demographic consequences are also recorded on the regional level [13] (pp. 73-76). OECD underlines the heterogeneity of the territorial impact of COVID-19, and it identifies its different dimensions related to health, economic, social, or fiscal impact [6]. The economic impact is reflected across the regions differently and is related to the exposure of regions to tradable sectors, to global value chains. Regional employment has also been affected [6]. The studies on the regional impact in certain countries confirm the heterogeneity of the local economic impact of COVID-19 in selected countries [14], i.e., in their specific areas both urban [15,16] and rural [17].

Böhme and Besana also point out high asymmetry of the territorial impact of COVID19 and they underline that it is due to the health repercussion of COVID-19 and the territorial dimension of policy responses. The exposure and sensitivity to COVID-19 policy responses differ and, hence, the territorial impact of the pandemic varies [18] (pp. 3-10). It is the result of policy responses timing and the length of lockdowns. The restrictions on 
mobility are also decisive for the differences in the intensity of the impact. The medium and long-term impact depends on the spread of the disease and its influence on the structure of the economy. The policy tools, also the financial ones, which support certain activities could influence the ability to reduce economic costs [12].

The impact of COVID-19 on subnational governments is worth mentioning. In the short- and medium-term, the impact on their finances due to a large increase in expenditures and decreasing revenues, so-called "scissors effect" is observed. The subnational governments have strong pressure to increase spending and the largest increase refers to social services, social benefits spending, including SMEs, the self-employed, public health, mostly these domains in which they have responsibilities. They are planning to borrow new funds to cover expenditures related to counteracting the negative effects of the pandemic instability and to introduce some recovery measures [19]. The multi-level governance framework is decisive for the scale of effect of the pandemic. If decentralisation is high, then a high impact on the subnational expenditures is also observed. The levels of government are affected differently, and delayed effects are recorded between regions due to the geographic localisation, socio-demographic profile, and their economic activities [6] (pp. 29-30).

Regional policies should respond to the current challenges, and top priorities for decision makers to be attained include access to basic services that are affordable and accessible across territories, promoting regional resilience, and counteracting digital divide. Regional and municipal respondents indicate that a transition to a sustainable and lowcarbon economy is also important when elaborating the regional development policy [19].

\subsection{Sustainable Regional Competitiveness at the Time of COVID-19 Instability}

European Union regions present different growth patterns and, therefore, the core and periphery spatial regime could be distinguished. The determinants of their growth differ (examining growth dynamics 2009-2015). Most CEE regions were classified among the regions in the peripheral spatial regime [20]. Therefore, they could also present different growth patterns under the pandemic. The group of newly admitted countries to the EU after 2004 is diversified as far as GDP growth rate in 2020/2019 is concerned. Selected CEE countries recorded a strong decrease in terms of GDP. In Croatia, for example, the GDP growth rate dropped to $-8.0 \%$, while in Lithuania to $-0.9 \%$, and Poland to $-2.7 \%$, due to pandemic repercussions [21]. The analysis of changes related to regional GDP in 2020 is not possible because of GDP data limitations on the EU regional level. However, the data concerning the unemployment rate are available and they show an increase in the unemployment rate to a varying extent (among people aged 15-74) in most of these regions compared to 2019 . In about $31 \%$ of the regions, the unemployment rate fell in 2020 in comparison with the previous year [22].

Considering the diversified impacts of the pandemic on the territorial units, the question is how to promote resilient regions in this turbulent time. If we employ a systemic perspective, then the concept of system resistance to shocks returning to a previous state could be adopted. However, sometimes it is not desirable or possible. Therefore, the complex adaptive system approach underlines the non-linear dynamics and also the adaptive capacity. Thus, resilience is not related to returning to normality but could be perceived through the prism of the capacity to adapt [23] (pp. 94-95). Referring to the discussion above the notion of resilience as an adaptation to some challenges and hereinafter the capability of local places and its governments to withstand the global economic punches while respecting environmental limits, external changes, and assuring high levels of social inclusion is also underlined [24,25]. If we adapt the notion of resilience to external shocks, then the adaptability of the system means resilience and the adaptive cycle model was proposed [26] (pp. 1306-1315). Taking into account different approaches towards resilience, we can assume that resilience enables the system of the regional economy as such to absorb and rebound from a shock to improve its performance through some changes of different 
nature (structural, functional, and organizational). Resilience of the particular region is reflected in its rate of growth [25], for example.

Promotion of competitiveness, which requires some changes to attain regional growth, can be regarded as a determinant of the resilience of the region [27]. The pandemic puts social and environmental issues $[28,29]$ on the agenda, which should be reflected in the current approach towards competitiveness.

In light of the aforementioned discussion, the concept of sustainable competitiveness whose promotion could keep the regions resilient in the face of social problems, growing polarization of societies, and environmental problems is of particular importance during the COVID-19 pandemic.

Aiginger, Bärenthaler-Sieber, and Vogel underline the need to redefine the competitiveness concept in relation to a region as its ability "to deliver the beyond-GDP goals for its citizens" [30] (p. 1). This concept captures the transition of the economy towards a more dynamic path of growth, more socially inclusive and environmentally sustainable, where the ultimate aim is the welfare of citizens. Under the new perspective, the facets of competitiveness should not be reduced to price competitiveness. A broader approach and interpretation also embrace the quality/technological competitiveness through the prism of sources of competitiveness and their prospects. During the transition to a new growth path, there are some components that are important including the capability of the social system (social aspect), and the ecological aspect, which could be the driver of economic growth [30] (pp. 9-14).

Sustainability is also underlined in another definition of regional competitiveness, according to which it is "the ability to offer an attractive and sustainable environment for firms and residents to live and work" [31] (p. 4). Thus, also including commercial and well-being goals [31] (p. 4). Corrigan et al. stress that sustainable competitiveness is "the set of institutions, policies, and factors that make a nation productive over the longer term while ensuring social and environmental sustainability" [32] (p. 55) and this concept has been adopted for the purpose of this paper. Social and environmental sustainability constitute an integral part of the concept of sustainable competitiveness. The concept of regional sustainable competitiveness at the time of the pandemic is presented in Figure 1, which underlines three main pillars (spheres) of sustainable competitiveness: economic, social, and environmental, which are adopted in this study to operationalise this concept.

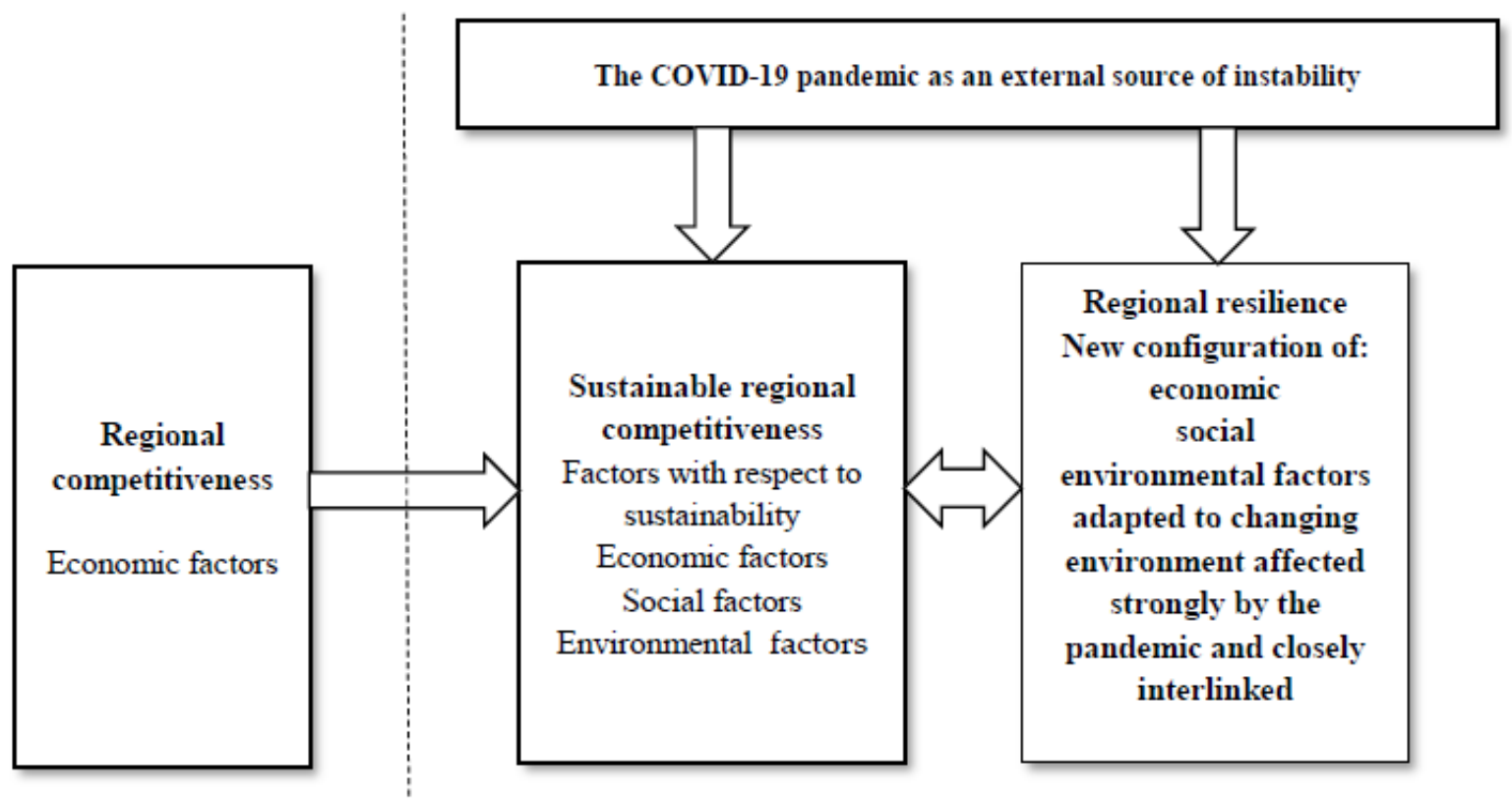

Figure 1. The concept of regional sustainable competitiveness at the time of the COVID-19 pandemic. Source: own elaboration. 
The resilience of regions is inevitably associated with the sustainable competitiveness. There is a question concerning factors that could contribute to the regional competitiveness with respect to its sustainability. The factors explaining regional competitiveness is widely recognized, which try to capture the complexity of this competitiveness [33]. They can be presented as the model, e. g., formed the regional hat [3]. However, the causes of sustainable competitiveness, due to the complexity of this notion are difficult to capture. Doyle 2017 reviewed a wide range of indicators referring to sustainable competitiveness and describing them as a set of elements, with economic performance being the central pillar and the social and environmental the domains [34]. Aiginger 2013 grouped these factors into the income, social, and ecological pillars from the country perspective [30]. This country perspective was adopted in another study [35].

Aiginger and Frigo present the drivers of regional competitiveness in the new perspective, which are innovation, education, institutions, social cohesion, and ecological ambitions [36]. However, there is a lack of consensus regarding the factors underpinning the regional sustainable competitiveness and its measurement.

\section{Materials and Methods}

Taking into account the aforementioned discussion, the paper aims at presenting not only the concept of sustainable competitiveness at the time of the pandemic but also at identifying factors that are decisive for regional competitiveness. CEE regions could be classified as the group which on average present a similar spatial pattern of growth. It is assumed that similar factors could determine sustainable competitiveness for the whole group of CEE regions. To attain the specified objective the following research questions have been formulated:

Research Question 1 (RQ1): What factors are essential for creating regional sustainable competitiveness?

Research Question 2 (RQ2): What is the position of CEE regions in terms of sustainable competitiveness?

The following thesis has been identified and formulated: The enhancement of sustainable regional competitiveness requires the promotion of relevant factors for each dimension of competitiveness, specific for CEE regions.

The competitiveness has been analysed in the group of 57 regions NUTS 2 level from the following CEE countries: Bulgaria (6), Czechia (8), Croatia (2), Hungary (8), Latvia (2), Poland (17), Romania (8), Slovenia (2), and Slovakia (4).

In order to answer the above research questions and verify the thesis, a factor analysis technique was used. Numerous studies of a country or a regional dimension are also related to innovativeness applied to the factor analysis [37-40].

The following steps in factor analysis were applied, on the basis of the literature review [41-44].

A large number of variables were collected, which described each of the competitiveness dimension for CEE regions: economic, social, and environmental. The data was derived from the database from the European Social Progress Index on the European regional level [45] and from the European Statistical Office [46]. It covers the period before the pandemic years, 2015-2020, depending on the indicator. In total, 59 variables were taken into consideration.

Then the variables that showed low coefficient of variations $10 \%$ or less were removed. The variables were standardized because they were presented in different units of measurement, and it was difficult to compare them. The correlation matrix was prepared for each of the dimension, which allowed us to show a high correlation among several variables. The significance of those links could explain the existing correlation between variables, and, thus, the rationale for using factor analysis. However, the variables with the correlation above $90 \%$ were excluded.

Factor analysis was preceded by calculating the value of the Kaiser-Meyer-Olkin measure (KMO). The Bartlett's test of sphericity was also applied in order to confirm that 
data reduction analysis produces a result that is meaningful. The Kaiser's criterion was used to select the number of factors.

The existing set of variables in each dimension was reduced to a certain number of hypothetical factors describing each of the dimension of sustainable competitiveness in the best possible way.

\section{The Results}

The economic dimension of competitiveness covers factors that contribute to high growth and productivity including institutions. The initial set of indicators covers 20 variables and finally, following the procedure indicated in the methodology part, they were reduced to 12 variables (Table 1). The analysis allows us to identify three factors characterising regional competitiveness that are related to education and human resources, institutions, and ICT development, which importance is confirmed in some studies.

The economic dimension of sustainable competitiveness comprises three factors (Table 1). Factor 1 referring to education and human resources well qualified. The first eigenvalue of 3.78 corresponds to this first factor that associated with $29 \%$ of the variance in the original data. The second eigenvalue is 3.13 and corresponds to $24 \%$ of the variance in the original data. The second factor relates to the institutional framework of regions. While the third eigenvalue is 3.93 and corresponds to $30.2 \%$ of the total variance in the data. Factor 3 consists of variables creating a conducive environment and framework for ICT development. The identified factor explained $83.2 \%$ of the initial variance of variable.

The achievement of a high social dimension of competitiveness determines high competitiveness because growth opportunities must be gained by each member of society. Therefore, the achievement of social inclusion and social cohesion is put on the agenda. If this dimension is associated with all the factors, institutions, and policies that make people healthy, active, and safe [32] (p. 55), a wide set of indicators could describe this dimension. This approach underlines that people enhance their potential to benefit from prosperity and they make some contribution [32] (p. 55). Initially, 35 indicators were selected for the analysis and they were reduced to twelve indicators (Table 2). The analysis revealed that three factors are important when social aspects are included in the concept of competitiveness. They are related to trust and support to government and the effectiveness of its activities, security, and environment, which is conducive to the development of the human-being.

The cumulative percentage of the total variance explained by the factors amounted to $76.1 \%$. The first eigenvalue corresponding to the first factor was equal to 3.37 and corresponds to $28 \%$ of the variance in the original data. Factor 1 related to the support for the government and policy effectiveness covers indicators concerning trust in the national government, the legal system, and the effectiveness of the policy to assure security. The second eigenvalue of 1.77 corresponds to the second factor that associated with $14.7 \%$ of variance in the original data. Factor 2 is related to personal security and safety. The third eigenvalue is 4.01 and corresponds to $33.4 \%$ of the variance in the original data. Factor 3 refers to conducive regional environment for health.

Finally, the environmental dimension of sustainable competitiveness could be characterised by institutions, policies, and factors to assure the management of resources in an efficient way. However, the prosperity of generations must also be attained [32] (p. 55). Initially, four variables were taken into consideration, but they were reduced to three variables. The only one eigenvalue that was equal to 2.196 corresponds to $73.2 \%$ of the total variance in the original data (Table 3). 
Table 1. Economic dimension of regional competitiveness-latent factors, and variables.

\begin{tabular}{|c|c|c|c|c|c|c|c|c|}
\hline Variable & $\begin{array}{l}\text { Factor 1 } \\
\text { Education and Human } \\
\text { Resources Well } \\
\text { Qualified }\end{array}$ & $\begin{array}{c}\text { Factor } 2 \\
\text { Institutions }\end{array}$ & $\begin{array}{l}\text { Factor } 3 \\
\text { ICT Development }\end{array}$ & $\begin{array}{l}\text { Total Variance } \\
\text { Explained }\end{array}$ & КМO & $\begin{array}{l}\text { Bartlett's Test of } \\
\text { Sphericity }\end{array}$ & & \\
\hline $\begin{array}{l}\text { Upper-secondary enrolment rate (percentage of } \\
\text { 14-18-year-old students enrolled) }\end{array}$ & 0.615 & & & & 0.843 & Chi Squared & Df & $\begin{array}{c}\text { Sigerception of } \\
\text { competitiveness in the } \\
\text { context of nificance }\end{array}$ \\
\hline $\begin{array}{c}\text { Lower-secondary completion only (percentage of people } \\
\text { aged } 25 \text { to } 64 \text { who have successfully completed, at most, } \\
\text { lower-secondary education) }\end{array}$ & 0.628 & & & & & 765.147 & 78 & 0.000 \\
\hline $\begin{array}{l}\text { Tertiary education attainment (percentage of population } \\
\text { aged 25-64 with tertiary education attainment) }\end{array}$ & 0.949 & & & & & & & \\
\hline Disposable income in PPS per inhabitant & 0.764 & & & & & & & \\
\hline $\begin{array}{l}\text { Institution quality index (quality and accountability of } \\
\text { government services) }\end{array}$ & & 0.784 & & & & & & \\
\hline $\begin{array}{l}\text { Institution corruption index (perceived level of } \\
\text { corruption) }\end{array}$ & & 0.910 & & & & & & \\
\hline $\begin{array}{l}\text { Institution impartiality index (level of impartiality of } \\
\text { government services) }\end{array}$ & & 0.836 & & & & & & \\
\hline $\begin{array}{l}\text { Online interaction with public authorities (percentage of } \\
\text { individuals who used the internet to interact with public } \\
\text { authorities) }\end{array}$ & & & 0.773 & & & & & \\
\hline $\begin{array}{l}\text { Internet access (share of people who declared they have } \\
\text { access whether on a mobile phone, a computer, or } \\
\text { another device) }\end{array}$ & & & 0.880 & & & & & \\
\hline $\begin{array}{l}\text { Lifelong learning (percentage of people aged } 25 \text { to } 64 \\
\text { who stated that they have received education or training } \\
\text { in the four weeks preceding the survey) }\end{array}$ & & & 0.843 & & & & & \\
\hline Total intramural R\&D expenditure as a $\%$ of GDP & & & 0.738 & & & & & \\
\hline Eigenvalue & 3.775 & 3.125 & 3.927 & & & & & \\
\hline$\%$ variance & 29.0 & 24.0 & 30.2 & 83.2 & & & & \\
\hline
\end{tabular}


Table 2. Social dimension of regional competitiveness-latent factors and variables.

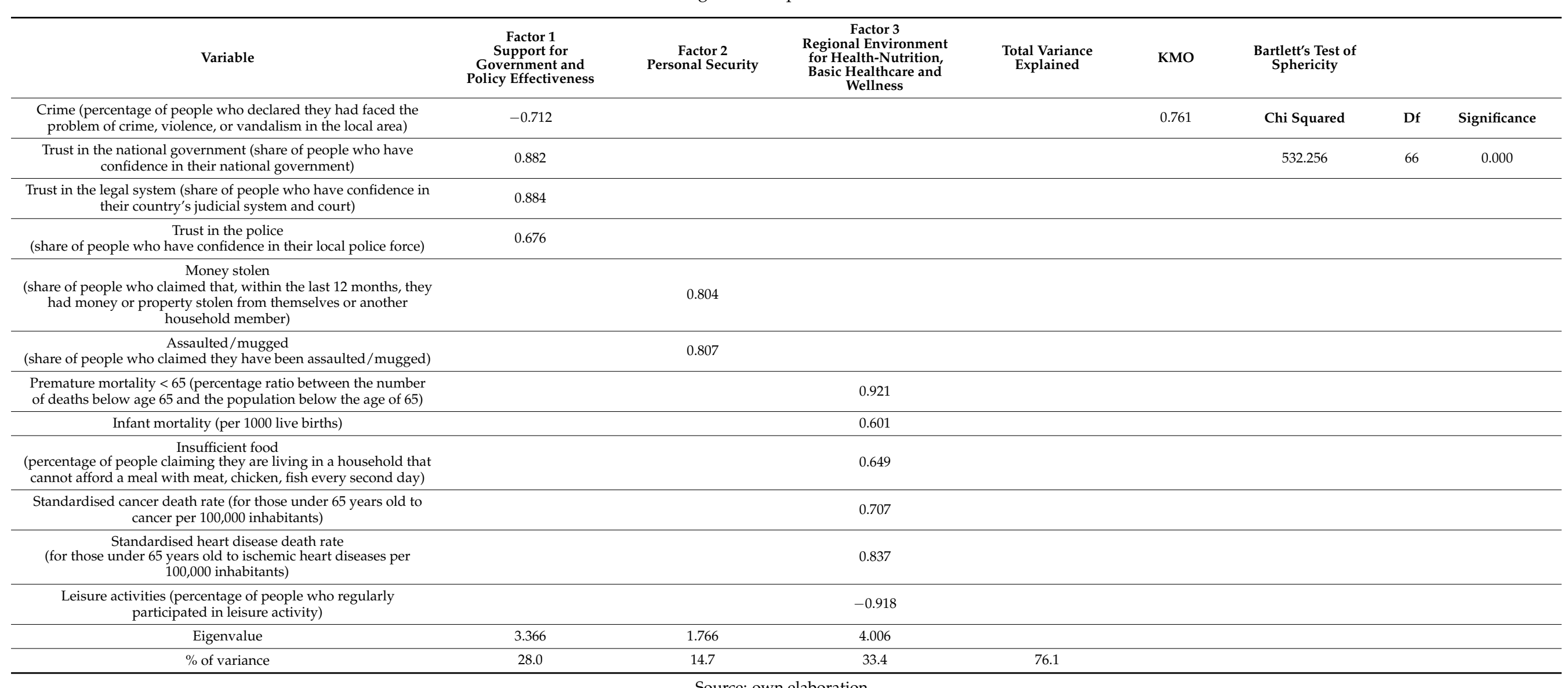

Source: own elaboration 
Table 3. Environmental dimension of regional competitiveness-latent factor, and variables.

\begin{tabular}{cc}
\hline Variable & Factor $\mathbf{1}$ \\
\hline Air pollution $\mathrm{NO}_{2}$ & -0.616667 \\
\hline Air pollution $\mathrm{PM}_{2.5}$ & -0.938803 \\
\hline Air pollution $\mathrm{PM}_{10}$ & -0.966553 \\
\hline Eigenvalue & 2196 \\
\hline \% of variance & 73.2 \\
\hline
\end{tabular}

Source: own elaboration.

The question is (RQ2): What is the position of CEE regions in terms of sustainable competitiveness? To answer this question, we used the sum of standardized variables (SSV), which was calculated for each of the dimension of competitiveness and for sustainable competitiveness treated as the total and then presented them in the ranking (Tables 4 and 5). The Czech regions are characterized by high sustainable competitiveness. The highest position in the ranking was taken by the two Czech regions because they are characterised by the highest value of SSV. Six out of eight Czech regions were classified among the tenth best regions. The last positions in the general ranking of sustainable competitiveness were taken by Romanian and Bulgarian regions.

Table 4. The rank of regions in terms of sustainable competitiveness according to the sum of standardized variables.

\begin{tabular}{|c|c|c|c|}
\hline NUTS 2 Region & Region's Name & Ranking & SSV \\
\hline CZ01 & Praha & 1 & 1.0749 \\
\hline CZ06 & Jihovýchod & 2 & 0.9215 \\
\hline SI04 & Zahodna Slovenija & 3 & 0.8501 \\
\hline CZ03 & Jihozápad & 4 & 0.7706 \\
\hline SK01 & Bratislavský kraj & 5 & 0.7517 \\
\hline PL91 & Warszawski stołeczny & 6 & 0.7323 \\
\hline CZ02 & Střední Čechy & 7 & 0.7201 \\
\hline CZ07 & Střední Morava & 8 & 0.7152 \\
\hline CZ05 & Severovýchod & 9 & 0.6996 \\
\hline SI03 & Vzhodna Slovenija & 10 & 0.6904 \\
\hline LT01 & Sostinès regionas & 11 & 0.5441 \\
\hline PL63 & Pomorskie & 12 & 0.5111 \\
\hline PL21 & Małopolskie & 13 & 0.4853 \\
\hline LT02 & Vidurio ir vakaru Lietuvos regionas & 14 & 0.4579 \\
\hline PL84 & Podlaskie & 15 & 0.4417 \\
\hline CZ08 & Moravskoslezsko & 16 & 0.3954 \\
\hline PL92 & Mazowiecki regionalny & 17 & 0.3091 \\
\hline HU11 & Budapest & 18 & 0.2905 \\
\hline PL82 & Podkarpackie & 19 & 0.2839 \\
\hline PL81 & Lubelskie & 20 & 0.2757 \\
\hline PL51 & Dolnośląskie & 21 & 0.2710 \\
\hline
\end{tabular}


Table 4. Cont.

\begin{tabular}{|c|c|c|c|}
\hline NUTS 2 Region & Region's Name & Ranking & SSV \\
\hline PL22 & Śląskie & 22 & 0.2262 \\
\hline PL41 & Wielkopolskie & 23 & 0.2059 \\
\hline PL52 & Opolskie & 24 & 0.2037 \\
\hline HU22 & Nyugat-Dunántúl & 25 & 0.1968 \\
\hline PL42 & Zachodniopomorskie & 26 & 0.1861 \\
\hline SK02 & Západné Slovensko & 27 & 0.1640 \\
\hline PL62 & Warmińsko-mazurskie & 28 & 0.1517 \\
\hline PL61 & Kujawsko-pomorskie & 29 & 0.1277 \\
\hline HR03 & Jadranska Hrvatska & 30 & 0.1228 \\
\hline HU21 & Közép-Dunántúl & 31 & 0.1141 \\
\hline PL72 & Świętokrzyskie & 32 & 0.1033 \\
\hline PL43 & Lubuskie & 33 & 0.0952 \\
\hline CZ04 & Severozápad & 34 & 0.0884 \\
\hline HU12 & Pest & 35 & 0.0574 \\
\hline PL71 & Łódzkie & 36 & 0.0123 \\
\hline HU33 & Dél-Alföld & 37 & -0.0058 \\
\hline SK03 & Stredné Slovensko & 38 & -0.0627 \\
\hline SK04 & Východné Slovensko & 39 & -0.1325 \\
\hline HU23 & Dél-Dunántúl & 40 & -0.1674 \\
\hline HR04 & Kontinentalna Hrvatska & 41 & -0.2814 \\
\hline RO32 & Bucureşti-Ilfov & 42 & -0.3907 \\
\hline HU32 & Észak-Alföld & 43 & -0.3921 \\
\hline HU31 & Észak-Magyarország & 44 & -0.5378 \\
\hline $\mathrm{RO} 42$ & Vest & 45 & -0.6068 \\
\hline RO12 & Centru & 46 & -0.7072 \\
\hline BG41 & Yugozapaden & 47 & -0.7378 \\
\hline BG32 & Severen tsentralen & 48 & -0.7705 \\
\hline RO11 & Nord-Vest & 49 & -0.8034 \\
\hline RO31 & Sud-Muntenia & 50 & -0.8810 \\
\hline $\mathrm{RO} 41$ & Sud-Vest Oltenia & 51 & -0.8914 \\
\hline BG33 & Severoiztochen & 52 & -0.9131 \\
\hline BG42 & Yuzhen tsentralen & 53 & -1.0091 \\
\hline $\mathrm{RO} 21$ & Nord-Est & 54 & -1.0311 \\
\hline BG34 & Yugoiztochen & 55 & -1.2376 \\
\hline $\mathrm{RO} 22$ & Sud-Est & 56 & -1.2539 \\
\hline BG31 & Severozapaden & 57 & -1.4348 \\
\hline
\end{tabular}


Table 5. Ranking of NUTS 2 regions of CEE countries according to each dimension of sustainable competitiveness with the use of the SSV.

\begin{tabular}{|c|c|c|c|c|c|c|c|c|}
\hline Ranking & $\begin{array}{l}\text { NUTS } 2 \\
\text { Region }\end{array}$ & Economic & Ranking & $\begin{array}{l}\text { NUTS2 } \\
\text { Region }\end{array}$ & Social & Ranking & $\begin{array}{l}\text { NUTS } 2 \\
\text { Region }\end{array}$ & Environmental \\
\hline 54 & BG31 & -1.39948 & 57 & BG31 & -1.64569 & 48 & BG31 & -0.74413 \\
\hline 46 & BG32 & -0.73272 & 52 & BG32 & -0.93928 & 40 & BG32 & -0.25924 \\
\hline 48 & BG33 & -0.91128 & 55 & BG33 & -1.18319 & 21 & BG33 & 0.159244 \\
\hline 55 & BG34 & -1.42228 & 56 & BG34 & -1.24928 & 46 & BG34 & -0.39018 \\
\hline 35 & BG41 & 0.019788 & 54 & BG41 & -1.15619 & 57 & BG41 & -2.34691 \\
\hline 49 & BG42 & -1.06238 & 51 & BG42 & -0.89043 & 52 & BG42 & -1.25313 \\
\hline 1 & CZ01 & 1.658575 & 3 & CZ01 & 0.758667 & 38 & CZ01 & -0.18925 \\
\hline 10 & CZ02 & 0.724649 & 7 & CZ02 & 0.706577 & 11 & CZ02 & 0.754623 \\
\hline 9 & CZ03 & 0.727273 & 8 & CZ03 & 0.686977 & 4 & CZ03 & 1.293131 \\
\hline 39 & CZ04 & -0.15606 & 30 & CZ04 & 0.173765 & 9 & CZ04 & 0.806084 \\
\hline 11 & CZ05 & 0.695327 & 5 & CZ05 & 0.724501 & 13 & CZ05 & 0.618932 \\
\hline 5 & CZ06 & 1.137309 & 6 & CZ06 & 0.715604 & 8 & CZ06 & 0.809928 \\
\hline 7 & CZ07 & 0.78231 & 2 & CZ07 & 0.784509 & 24 & CZ07 & 0.147501 \\
\hline 14 & CZ08 & 0.633401 & 14 & CZ08 & 0.509657 & 50 & CZ08 & -1.09316 \\
\hline 41 & HR03 & -0.35691 & 20 & HR03 & 0.319109 & 2 & HR03 & 1.416537 \\
\hline 43 & HR04 & -0.4067 & 38 & HR04 & -0.12678 & 44 & HR04 & -0.35659 \\
\hline 8 & HU11 & 0.760505 & 26 & HU11 & 0.211458 & 53 & HU11 & -1.42988 \\
\hline 33 & HU12 & 0.030678 & 27 & HU12 & 0.197842 & 45 & HU12 & -0.38852 \\
\hline 36 & HU21 & -0.02179 & 29 & HU21 & 0.188534 & 18 & HU21 & 0.405661 \\
\hline 37 & HU22 & -0.03546 & 19 & HU22 & 0.358298 & 15 & HU22 & 0.557692 \\
\hline 42 & HU23 & -0.39582 & 35 & HU23 & -0.00121 & 22 & HU23 & 0.157532 \\
\hline 45 & HU31 & -0.50113 & 45 & HU31 & -0.63387 & 42 & HU31 & -0.31289 \\
\hline 44 & HU32 & -0.422 & 43 & HU32 & -0.43422 & 35 & HU32 & -0.09373 \\
\hline 28 & HU33 & 0.085499 & 37 & HU33 & -0.11039 & 32 & HU33 & 0.016934 \\
\hline 4 & LT01 & 1.173505 & 41 & LT01 & -0.35365 & 3 & LT01 & 1.407219 \\
\hline 13 & LT02 & 0.63728 & 39 & LT02 & -0.13458 & 1 & LT02 & 2.050828 \\
\hline 16 & PL21 & 0.530898 & 1 & PL21 & 0.934769 & 55 & PL21 & -1.51041 \\
\hline 17 & PL22 & 0.394384 & 11 & PL22 & 0.578337 & 56 & PL22 & -1.91083 \\
\hline 19 & PL41 & 0.307177 & 25 & PL41 & 0.226379 & 43 & PL41 & -0.31471 \\
\hline 26 & PL42 & 0.118591 & 33 & PL42 & 0.061329 & 6 & PL42 & 0.97777 \\
\hline 32 & PL43 & 0.034666 & 34 & PL43 & 0.041059 & 14 & PL43 & 0.574489 \\
\hline 18 & PL51 & 0.371919 & 22 & PL51 & 0.264102 & 37 & PL51 & -0.13892 \\
\hline 20 & PL52 & 0.217502 & 18 & PL52 & 0.367541 & 47 & PL52 & -0.51137 \\
\hline 23 & PL61 & 0.176533 & 31 & PL61 & 0.118998 & 33 & PL61 & -0.0492 \\
\hline 38 & PL62 & -0.03553 & 28 & PL62 & 0.194855 & 10 & PL62 & 0.790263 \\
\hline 15 & PL63 & 0.563143 & 21 & PL63 & 0.307312 & 5 & PL63 & 1.100353 \\
\hline 25 & PL71 & 0.155975 & 32 & PL71 & 0.106845 & 49 & PL71 & -0.9881 \\
\hline 30 & PL72 & 0.05956 & 23 & PL72 & 0.248393 & 41 & PL72 & -0.28799 \\
\hline 24 & PL81 & 0.168707 & 17 & PL81 & 0.421576 & 23 & PL81 & 0.156153 \\
\hline 29 & PL82 & 0.074035 & 12 & PL82 & 0.576304 & 31 & PL82 & 0.023956 \\
\hline 22 & PL84 & 0.177908 & 10 & PL84 & 0.606749 & 7 & PL84 & 0.924312 \\
\hline 2 & PL91 & 1.287123 & 9 & PL91 & 0.608104 & 51 & PL91 & -1.17513 \\
\hline 21 & PL92 & 0.202574 & 16 & PL92 & 0.478546 & 26 & PL92 & 0.092696 \\
\hline 50 & RO11 & -1.13899 & 47 & RO11 & -0.67062 & 25 & RO11 & 0.120026 \\
\hline 51 & RO12 & -1.16171 & 42 & RO12 & -0.41188 & 28 & RO12 & 0.080779 \\
\hline 56 & RO21 & -1.5331 & 50 & RO21 & -0.76727 & 27 & RO21 & 0.088861 \\
\hline 57 & $\mathrm{RO} 22$ & -1.69999 & 53 & $\mathrm{RO} 22$ & -1.09148 & 30 & RO22 & 0.029882 \\
\hline 52 & RO31 & -1.2569 & 48 & RO31 & -0.67468 & 34 & RO31 & -0.07738 \\
\hline 27 & RO32 & 0.091076 & 46 & RO32 & -0.64777 & 54 & RO32 & -1.4505 \\
\hline 53 & RO41 & -1.2794 & 49 & RO41 & -0.70367 & 29 & RO41 & 0.038669 \\
\hline
\end{tabular}


Table 5. Cont.

\begin{tabular}{|c|c|c|c|c|c|c|c|c|}
\hline Ranking & $\begin{array}{c}\text { NUTS } 2 \\
\text { Region }\end{array}$ & Economic & Ranking & $\begin{array}{l}\text { NUTS2 } \\
\text { Region }\end{array}$ & Social & Ranking & $\begin{array}{l}\text { NUTS } 2 \\
\text { Region }\end{array}$ & Environmental \\
\hline 47 & $\mathrm{RO} 42$ & -0.90951 & 44 & $\mathrm{RO} 42$ & -0.49557 & 19 & $\mathrm{RO} 42$ & 0.260415 \\
\hline 12 & SI03 & 0.669559 & 4 & SI03 & 0.727831 & 12 & SI03 & 0.631216 \\
\hline 3 & SI04 & 1.26849 & 13 & SI04 & 0.552863 & 20 & SI04 & 0.226439 \\
\hline 6 & SK01 & 1.046799 & 15 & SK01 & 0.50548 & 16 & SK01 & 0.457943 \\
\hline 34 & SK02 & 0.029645 & 24 & SK02 & 0.244602 & 17 & SK02 & 0.423977 \\
\hline 31 & SK03 & 0.043716 & 40 & SK03 & -0.16206 & 36 & SK03 & -0.12605 \\
\hline 40 & SK04 & -0.21694 & 36 & SK04 & -0.02372 & 39 & SK04 & -0.20182 \\
\hline
\end{tabular}

The rankings of regions according to each dimension of sustainable competitiveness allows us to identify some regions that have a similar position in terms of the economic and social dimensions. There are also regions whose positions in both rankings are diversified and this needs further studies.

To measure the strength and direction of relationship between two dimensions of sustainable competitiveness, Spearman's rank-order correlation was adopted. It showed monotonic association between economic and social dimension of sustainable competitiveness. Spearman's correlation coefficient stood at rs $=0.799002$. However, there is no correlation between ranks of the environmental dimension of sustainable competitiveness and other dimensions, i.e., economic and social ones, assuming the adopted data.

\section{Discussion}

During an unstable economic situation, including a pandemic, the achievement of growth should be beneficial for all members of society and without a detrimental effect on the environment. Thus, the concept of sustainable regional competitiveness should be strongly promoted. There are some methods allowing us to measure competitiveness, e.g., a Cobb-Douglas production function [47], multiple-criteria decision making techniques [48], the taxonomic methods [49] or the factor analysis. The factor analysis applied in this study enabled us not only to reduce the number of variables but also to identify a limited number of factors--pillars--of each dimension of competitiveness. Then, the SSV allowed us to create the ranking of the regions of CEE countries.

The ranking of regions in terms of competitiveness have also been constructed, i.e., regional competitiveness index [33,50] and others [51]. However, it is difficult to make comparisons between rankings due to different factors/indicators included in the index.

The conducted analysis in this paper identified some factors specific for regional competitiveness, the importance of which was confirmed in some studies.

The economic dimension of sustainable competitiveness refers to human capital, fundamental for economic growth. Human capital is essential for the new economy and knowledge-based activities. It is reflected on the education level and its capacity for the modern economy supported by the available financial resources as well as in stock of human capital described by employment in high-tech sectors (human resources in science and technology). The level of education is an important driver of productivity [3] (pp. 3-35). Thus, human capital constitutes a driver of competitiveness being the primary factor in the regional investment climate [3] (pp. 2-37).

The factor: Institutions contribute to competitiveness. However, the further question is: what kind of institution matters? No one size fits all, different institutional arrangements are required, "there is a lack of consensus as to whether institutions are a prerequisite or a natural outcome of development" [52] (pp. 14-15). Institutions are crucial for facilitating the input to be transferred to high-value outcomes. Institutional enablers determine the potential for competitiveness, being the most important factor in the regional system [53]. High quality institutions have a significant impact on entrepreneurship and economic growth [54]. 
ICT and the potential to develop in this dimension is key issue nowadays. The factor related to ICT is often neglected in the studies on regional competitiveness. Digital transformation can boost economic growth as well as economic cooperation, best exemplified by western Balkan countries [55]. Some studies underline the role of ICT for competitiveness [56,57]. However, they confirm that the promotion of regional competitiveness through ICT seems to be a difficult process, which could also lead to growing disparities [58]. The regions should be smart as well as cities [59].

The social aspect of competitiveness should be taken into consideration including qualitative factors. The conducted analysis revealed some decisive factors for the social aspect of regional competitiveness: nutrition, basic healthcare, health, and wellness, which constitute important factors for the social dimension of competitiveness. The identified factors are confirmed in the literature and relate to these factors that characterise social cohesion.

These factors refer to the favourable living conditions, quality of life. They also refer to social cohesion, which can be perceived and measured by the inequality dimension regarding the factors mentioned above, also promoting and reducing disparities in terms of health status and basic healthcare [60]. It can be perceived as and measured by the existing social disparities reflected in different indicators [61] (pp. 21-23) and related to social cohesion in terms of social relations and interconnectedness with a political outcome, wellbeing, equity, and political order [62] (p. 11). The Council of Europe perceived social cohesion through the prism of society's ability to secure long-term well-being [63] (p. 23).

The second identified factor, i.e., the support for the government and policy effectiveness covers variables related to security and trust in institutions, which in the analyses relates to social capital dimension [60]. Social cohesion or "a cohesive society is characterised by resilient social relations, a positive emotional connectedness between its members and the community and a pronounced focus on common goods" [64] (p. 13). Three domains can be mentioned here: connectedness, social networks and focus on the common goods [64], and, as Jenson indicates, social cohesion as trust [61] (p. 24). Besides, the level of crime in deprived areas is related to social cohesion [65].

The third factor relates to personal security reflected in the indicators referring to violence [66]. Good social protection, and quality of governance and public institutions are essential. It also describes social protection and state-building [62] (p. 5).

The social, environmental, and economic factors should be the mutual reinforcing dimensions that creates resilient regions.

The regions of CEE do not present a homogenous group in terms of sustainable competitiveness and could have the potential to create resilient economy at the time of the pandemic. They are differently equipped with all these factors and must create their own combination of factors that constitute this kind of regional competitiveness.

This study allows us to identify factors that could contribute to sustainable competitiveness in regions of the CEE countries. However, it is a preliminary study that needs further conceptualization, especially the significance of identified factors from the pandemic perspective. This study has some practical significance. The proposed factors characterising the dimension of sustainable competitiveness may be taken into consideration by public authorities while planning interventions in the regions. The created rankings in each sphere of competitiveness and generally in competitiveness allow us to identify the position of each region in the group and elaborate such activities to be implemented that may contribute to enhancing specific factors of competitiveness.

\section{Conclusions}

The COVID-19 pandemic affected regional economies in a diversified way. Its repercussions are reflected in many spheres: economic, social, and environmental. The concept of sustainable regional competitiveness is under consideration and deeply discussed particularly at this turbulent time when keeping resilience and enhancing growth in regions are necessary. 
The analysis allows us to identify the factors that are decisive for each dimension of sustainable regional competitiveness in the regions of CEE countries, the promoting of which will allow us to achieve long-term growth beneficial not only from an economic but also social and environmental perspectives. The regions of the CEE countries that were taken into consideration are diversified as far as all the dimensions of sustainable competitiveness are concerned. However, while ranking of regions in terms of competitiveness in relation to social and economic dimensions, the relationship was proved. The study could be a starting point for discussion on measurement of regional competitiveness from the sustainability perspective.

The conducted study has various limitations. Firstly, the limitations of data that is available and its completeness. Especially the environmental dimension of regional competitiveness requires its extension of variables. Secondly, the analysed period, which refers to the time before the COVID-19 pandemic, should be extended to the pandemic time as soon as the data is available to capture the changes that were observed.

This research has some policy implications. It gives us some preliminary indication of what should be done to promote sustainable competitiveness of regions, but it requires further studies.

Further research should cover a wider period of time to present the changes that took place during the pandemic. The research should not be limited to the regions of countries admitted to the EU in 2004 and after 2004, but to the regions of other EU countries in order to verify if the factors selected are the same for the group of regions from the countries that are diversified in terms of sustainable competitiveness. The dynamic analysis is also recommended. All this will be taken into consideration in the further research.

Funding: This research was funded from the University of Economics in Katowice, Poland.

Institutional Review Board Statement: Not applicable.

Informed Consent Statement: Not applicable.

Data Availability Statement: Data can be obtained from: European Social Progress Index, Raw Data. Available online: https:/ / ec.europa.eu/regional_policy/en/information/maps/social_progress2 020/ (accessed on 19 January 2021); Eurostat Data Base. Available online: https:/ / ec.europa.eu/ eurostat/data/database (accessed on 19 January 2021).

Conflicts of Interest: The author declares no conflict of interest.

\section{References}

1. Balkytè, A.; Peleckis, K. Mapping the future sustainable competitiveness resources: Aspects of forests ownership. J. Bus. Econ. Manag. 2010, 11, 630-651. [CrossRef]

2. Balkyte, A.; Tvaronavičiene, M. Perception of competitiveness in the context of sustainable development: Facets of "sustainable competitiveness". J. Bus. Econ. Manag. 2010, 11, 341-365. [CrossRef]

3. Martin, R.L. A Study on the Factors of Regional Competitiveness. A Draft Final Report for the European Commission Directorate-General Regional Policy; Cambridge Econometrics: Cambridge, UK, 2003.

4. Okunevičiūtè Neverauskienè, L.; Danilevičienė, I.; Tvaronavičienė, M. Assessment of the factors influencing competitiveness fostering the country's sustainability. Econ. Res.-Ekon. Istraživanja 2020, 33, 1909-1924. [CrossRef]

5. Dziembała, M. The role of EU cohesion policy in promoting smart and sustainable competitiveness in the regions of the Visegrad countries. J. Sci. Technol. Policy Manag. 2020, 11, 325-341. [CrossRef]

6. The Territorial Impact of COVID-19: Managing the Crisis across Levels of Government, 10 November 2020, OECD 2020. Available online: https:/ / read.oecd-ilibrary.org/view / ?ref=128_128287-5agkkojaaa\&title=The-territorial-impact-of-Covid-19 -managing-the-crisis-across-levels-of-government (accessed on 21 February 2021).

7. Chudik, A.; Mohaddes, K.; Hashem Pesaran, M.; Raissi, M.; Rebucci, A. Economic Consequences of Covid-19: A Counterfactual Multi-Country Analysis. 19 October 2020. Available online: https://voxeu.org/article/economic-consequences-Covid-19-multicountry-analysis (accessed on 19 February 2021).

8. ILO. The Impact of the COVID-19 Pandemic on Jobs and Incomes in G20 Economies, ILO-OECD Paper Prepared at the Request of G20 Leaders Saudi Arabia's G20 Presidency 2020, OECD, ILO 2020. Available online: https: / www.ilo.org/wcmsp5/groups / public/---dgreports/---cabinet/documents/publication/wcms_756331.pdf (accessed on 24 August 2021).

9. Impact of the COVID-19 Pandemic on Trade and Development. Transitioning to a New Normal, United Nations 2020. Available online: https:/ / unctad.org/system/files/official-document/osg2020d1_en.pdf (accessed on 24 August 2021). 
10. The long-term impact of COVID-19 on poverty, UN/DESA Policy Brief No 86, United Nations, Department of Economic and Social Affairs, October 2020, pp. 1-5. Available online: https://www.un.org/development/desa/dpad/wp-content/uploads/ sites/45/publication/PB_86.pdf (accessed on 1 September 2021).

11. Mofijur, M.; Rizwanul Fattah, I.M.; Asraful Alam, M.; Saiful Islam, A.B.M.; Chyuan Ong, H.; Ashrafur Rahman, S.M.; Najafi, G.; Ahmed, S.F.; Alhaz Uddin, M.; Mahlia, T.M.I. Impact of COVID-19 on the social, economic, environmental and energy domains: Lessons learnt from a global pandemic. Sustain. Prod. Consum. 2021, 26, 343-359. [CrossRef]

12. Bailey, D.; Clark, J.; Colombelli, A.; Corradini, C.; De Propis, L.; Derudder, B.; Fratesi, U.; Fritsch, M.; Harrison, J.; Hatfield, M.; et al. Regions in a time of pandemic. Reg. Stud. 2020, 54, 1163-1174. [CrossRef]

13. EU Annual Regional and Local Barometer, Full Report, 2020 Barometer of Regions and Cities, European Committee of the Regions, Brussels. 2 October 2020. Available online: https://cor.europa.eu/en/our-work/Pages/EURegionalBarometer-2020.aspx (accessed on 24 August 2021).

14. Cerqua, A.; Letta, M. Local Inequalities of the COVID-19 Crisis. 18 December 2020. Available online: https://voxeu.org/article/ local-inequalities-Covid-19-crisis (accessed on 2 September 2021).

15. Policy Brief: COVID-19 in an Urban World, July 2020, United Nations. Available online: https://unsdg.un.org/resources/policybrief-Covid-19-urban-world (accessed on 18 August 2021).

16. Sharifi, A.; Khavarian-Garmsir, A.R. The COVID-19 pandemic: Impacts on cities and major lessons for urban planning, design, and management. Sci. Total. Environ. 2020, 749, 142391. [CrossRef]

17. Mueller, J.T.; McConnell, C.; Burow, P.B.; Pofahl, K.; Merdjanoff, A.A.; Farrell, J. Impacts of the COVID-19 pandemic on rural America. Proc. Natl. Acad. Sci. USA 2021, 118, 2019378118. [CrossRef]

18. Böhme, K.; Besana, F. Uderstanding the Territorially Diverse Implications of COVID-19 Policy Responses; Spatial Foresight GmbH: Luxembourg, 2020.

19. The Impact of COVID-19 on EU Regional and Local Governments: Main Findings from the Joint CoR-OECD Survey; OECD Regional Development Papers; OECD: Paris, France, 2020.

20. Annoni, P.; de Dominicis, L.; Khabirpour, N. Location matters: A spatial econometric analysis of regional resilience in the European Union. Growth Chang. 2019, 50, 824-855. [CrossRef]

21. Real GDP Growth Rate -Volume (Online Data Code: TEC00115). Eurostat. Available online: https://ec.europa.eu/eurostat/ databrowser/view/tec00115/default/table?lang=en (accessed on 18 August 2021).

22. Unemployment Rate Rose in the Majority of EU Regions in 2020, 28.04.2021, Eurostat. Available online: https:/ / ec.europa.eu/ eurostat/web/products-eurostat-news/-/ddn-20210428-1 (accessed on 18 August 2021).

23. Bristow, G.; Healy, A. Building resilient regions: Complex adaptive systems and the role of policy intervention. Raumforsch. Raumordn. 2014, 72, 93-102. [CrossRef]

24. Ashby, J.; Cox, D.; McInroy, N.; Southworth, D. Delivering Economic Success: An International Perspective on Local Government as Stewards of Local Economic Resilience. 2008 Norfolk Trust Fellowship. Available online: https:/ / cles.org.uk/wp-content/ uploads /2011/01/An-international-perspective-on-local-government-as-stewards-of-local-economic-resilience.pdf (accessed on 1 September 2021).

25. Martin, R.; Sunley, P. On the Notion of Regional Economic Resilience: Conceptualisation and Explanation. 14 October 2013. Available online: http:/ / econ.geo.uu.nl/peeg/peeg1320.pdf (accessed on 19 August 2021).

26. Martin, R.; Sunley, P. Conceptualizing cluster evolution: Beyond the life cycle model? Reg. Stud. 2011, 45, 1299-1318. [CrossRef]

27. Martin, R.; Sunley, P. Competitiveness and regional economic resilience. In Handbook of Regions and Competitiveness, Contemporary Theories and Perspectives on Economic Development; Huggins, R., Thompson, P., Eds.; Edward Elgar Publishing: Cheltenham, UK; Northampton, MA, USA, 2017.

28. Responding to COVID-19 and Recovering Better: A Compilation by UN DESA, Policy Brief Series, Spring/Summer 2020, Published by the United Nations, Department of Economic and Social Affairs New York, New York 10017, United States of America. Available online: https://www.un.org/development/desa/en/wp-content/uploads/2020/07/PB-Compilation-final. pdf (accessed on 19 August 2021).

29. The Long-Term Environmental Implications of COVID-19, 31 May 2021, OECD. Available online: https://www.oecd.org/ coronavirus / policy-responses/the-long-term-environmental-implications-of-Covid-19-4b7a9937/ (accessed on 19 August 2021).

30. Aiginger, K.; Bärenthaler-Sieber, S.; Vogel, J. Competitiveness under New Perspectives, Working Paper no 44. October 2013. Available online: http:/ / www.oecd.org/economy/Competitiveness-under-New-Perspectives.pdf (accessed on 27 February 2021).

31. Dijkstra, L.; Annoni, P.; Kozovska, K. A New Regional Competitiveness Index: Theory, Methods and Findings; Working Papers 2/2011; European Union Regional Policy: Brussels, Belgium, 2011.

32. Corrigan, G.; Crotti, R.; Drzeniek Hanouz, M.; Serin, C. Assessing Progress toward Sustainable Competitiveness, Chapter 1.2. In The Global Competitiveness Report 2014-2015: Full Data Edition; Schwab, K., Ed.; World Economic Forum: Geneva, Switzerland, 2014.

33. Annoni, P.; Dijkstra, L. EU Regional Competitiveness Index; JRC, Publications Office of the European Union: Luxembourg, 2013.

34. Doyle, E.; Perez-Alaniz, M. From the Concept to the Measurement of Sustainable Competitiveness: Social and Environmental Aspects. Entrep. Bus. Econ. Rev. 2017, 5, 35-59. [CrossRef]

35. Cheba, K.; Szopik-Depczyńska, K. Sustainable competitiveness and responsible innovations-the case of the European Union countries. Prace Naukowe Uniwersytetu Ekonomicznego we Wroctawiu 2019, 63, 139-150. [CrossRef] 
36. Aginger, K.; Firgo, M. Regional Competitiveness under New Perspectives; WWWforEurope Policy Paper, No. 26; WWWforEurope: Vienna, Austria, 2015.

37. Bartels, F.L.; Koria, R.; Vitali, E. Barriers to innovation: The case of Ghana and its implications for developing countries. Triple Helix 2016, 3, 12. [CrossRef]

38. Geng, J.; Li, C. Empirical Research on the Spatial Distribution and Determinants of Regional E-Commerce in China: Evidence from Chinese Provinces. Emerg. Mark. Financ. Trade 2020, 56, 3117-3133. [CrossRef]

39. Matínez-Pellitero, M.; Buesa, M.; Heijs, J.; Baumert, T.J.Y. A Novel Way of Measuring Regional Systems of Innovation: Factor Analysis as a Methodological Approach, Documento de Trabajo No 60. 2008. Available online: https://eprints.ucm.es/id/eprint/ 7979/1/60-08.pdf (accessed on 1 September 2020).

40. Pinto, H. The diversity of innovation in the European Union: Mapping latent dimensions and regional profiles. Eur. Plan. Stud. 2009, 17, 303-326. [CrossRef]

41. A Practical Introduction to Factor Analysis: Exploratory Factor Analysis. Available online: https://stats.idre.ucla.edu/spss / seminars/introduction-to-factor-analysis/a-practical-introduction-to-factor-analysis/ (accessed on 1 September 2021).

42. DeCoster, J. Overview of Factor Analysis. 1 August 1998. Available online: http:/ / www.stat-help.com/factor.pdf (accessed on 1 September 2021).

43. Pohlmann, J.T. Use and interpretation of factor analysis. J. Educ. Res. 2004, 98, 14-22. [CrossRef]

44. Stanisz, A. Przystępny Kurs Statystyki z Zastosowaniem STATISTICA PL na Przykładach z Medycyny, t. 3 Analizy Wielowymiarowe; StatSoft Kraków: Kraków, Poland, 2007.

45. European Social Progress Index, Raw Data. Available online: https://ec.europa.eu/regional_policy/en/information/maps/ social_progress2020/ (accessed on 19 January 2021).

46. Eurostat Data Base. Available online: https:/ / ec.europa.eu/eurostat/data/database (accessed on 19 January 2021).

47. Simionescu, M.; Pelinescu, E.; Khouri, S.; Bilan, S. The Main Drivers of Competitiveness in the EU-28 Countries. J. Compet. 2021, 13, 129-145. [CrossRef]

48. Bilbao-Terol, A.; Arenas-Parra, M.; Onopko-Onopko, V. Measuring regional sustainable competitiveness: A multi-criteria approach. Oper. Res. 2019, 19, 637-660. [CrossRef]

49. Hellwig, Z. Zastosowanie metody taksonomicznej do typologicznego podziału krajów ze względu na poziom ich rozwoju oraz zasoby i strukture wykwalifikowanych kadr. Przeglad Statystyczny 1968, 4, 30.

50. European Regional Competitiveness Index. Available online: https://ec.europa.eu/regional_policy/en/information/maps/ regional_competitiveness / (accessed on 19 January 2021).

51. Sánchez de la Vega, J.C.; Buendía Azorín, J.D.; Calvo-Flores Segura, A.; Esteban Yago, M. A new measure of regional competitiveness. Appl. Econ. Anal. 2019, 27, 108-126. [CrossRef]

52. Rodríguez-Pose, A. Do Institutions Matter for Regional Development in the EU? Available online: https: / citeseerx.ist.psu.edu/ viewdoc/download?doi=10.1.1.584.7385\&rep=rep1\&type=pdf (accessed on 19 August 2021).

53. Huggins, R.; Thompson, P. Regional competitiveness: Theories and methodologies for empirical analysis. JCC Bus. Econ. Res. J. 2013, 6, 155-172. [CrossRef]

54. Khyareh, M.M.; Amini, H. Governance Quality, Entrepreneurship and Economic Growth. J. Compet. 2021, 13, 41-64. [CrossRef]

55. Broz, T.; Buturac, G.; Parežanin, M. Digital transformation and economic cooperation: The case of Western Balkan countries. Z $b$. Rad. Ekon. Fak. Rij. 2020, 38, 697-722. [CrossRef]

56. Karlsson, C.; Maier, G.; Trippl, M.; Siedschlag, I.; Owen, R.; Murphy, G. ICT and Regional Dynamics: A Literature Review; European Commission, Joint Research Centre, Institute for Prospective Technological Studies, Publications Office of the European Union: Luxembourg, 2010.

57. Stankovic, J.; Marjanovic, J.; Drezgic, I.S.; Popovic, Z. The Digital Competitiveness of European Countries: A Multiple-Criteria Approach. J. Compet. 2021, 13, 117-134. [CrossRef]

58. Camagni, R.; Capello, R. ICTs and territorial competitiveness in the era of internet. Ann. Reg. Sci. 2005, 39, 421-438. [CrossRef]

59. Visvizi, A.; Lytras, M. Sustainable Smart Cities and Smart Villages Research: Rethinking Security, Safety, Well-being, and Happiness. Sustainability 2019, 12, 215. [CrossRef]

60. Berger-Schmitt, R. Considering social cohesion in quality of life assessment: Concept and measurement. Soc. Indic. Res. 2002, 58, 403-428. [CrossRef]

61. Jenson, J. Defining and measuring social cohesion, Commonwealth Secretariat and United Nations Research Institute for Social Development 2010. Available online: https:/ / digitallibrary.un.org/record/785809 (accessed on 1 August 2021).

62. Social Protection and Its Contribution to Social Cohesion and State-Building, Federal Ministry for Economic Cooperation and Development. Available online: https://cdn.odi.org/media/documents/7759.pdf (accessed on 20 August 2021).

63. Concerted Development of Social Cohesion Indicators; Methodological guide; Council of Europe: Strasbourg, France, 2005.

64. Dragolov, G.; Ignácz, Z.; Lorenz, J.; Delhey, J.; Boehnke, K. Social Cohesion Radar. Measuring Common Goods. An International Comparison of Social Cohesion, Bertelsmann Stiftung. 2013. Available online: http://aei.pitt.edu/74134/ (accessed on 24 August 2021). 
65. Hirschfield, A.; Bowers, K.J. The effect of social cohesion on levels of recorded crime in disadvantaged areas. Urban Stud. 1997, 34, 1275-1295. [CrossRef]

66. Colletta, N.J.; Cullen, M.L. The Nexus between Violent Conflict, Social Capital and Social Cohesion. 2000. Available online: https://gsdrc.org/document-library/the-nexus-between-violent-conflict-social-capital-and-social-cohesion/ (accessed on 1 September 2021). 